\title{
Adoption of Modern Packaging Means as an Important Marketing Strategy for Cattle Feed Products: A Case Study in Eastern Up
}

\author{
Vinod Kumar Paswan*, Satya Prakash Yadav, Sahar Masud and Tanweer Alam \\ Department of Animal Husbandry and Dairying, Banaras Hindu University, India
}

Submission: March 14, 2017; Published: March 27, 2017

*Corresponding author: Vinod Kumar Paswan, Department of Animal Husbandry and Dairying, Banaras Hindu University, Institute of Agricultural Sciences, Varanasi-221 005, UP, India, Tel: +91 542 6701778; Email: amtanweer@rediffmail.com

\begin{abstract}
Cattle feed industry in India is gradually evolving into an organized sector and the feed manufactures are increasingly adopting modern and sophisticated methods and marketing strategies in this sector. However, the feed industry sector has failed to attract the attention of the packaging industry and personnel which is one of the hindrances in order to promote this segment by incorporating modernized convenient and attractive packaging means. Therefore, this article presents an understanding of change in consumption pattern of branded and nonbranded compounded cattle feed, change in the demand for packaged cattle feed and attitudes of the dairy farmers towards incorporation of modernized quality in packaging of compounded cattle feed through a case study conducted in Varanasi district of Eastern UP. The study clearly reveals the preference of branded and packaged compounded cattle feed with suitable, convenient packaging material with attractive design and colour combination for which farmers are even ready to pay extra price. Therefore, the compounded cattle feed industry must adopt modern packaging technologies with latest packaging material and design in order to enhance sale and profitability and reduce wastage and deterioration in quality the compounded feed.
\end{abstract}

Keywords: Compounded cattle feed; Feed industry; Packaging

\section{Introduction}

The livestock sector has emerged as one of the fastest growing agricultural sub-sectors in India. It is expected that the growth could further accelerate due to growing income and the high-income driven demand for livestock products [1]. Cattle feed industry- a major component of animal feed industry is currently evolving from a fragmented industry into an organized sector [2-4]. The feed manufactures are increasingly adopting modern and sophisticated methods in an effort to incorporate best global practices. The concept of branded animal feed as a packaged commodity, though not a very recent concept, is gaining popularity in Indian context [5]. The packaged feed, as a product, possesses special features like hygiene, quality, convenience to handle and influences buying behaviour of the farmers. The importance of packaging can best be understood by the example of the introduction of sachet which made the shampoo available and affordable to the millions of the rural people in our country even in the far remote area of the countryside. However, these convenient and small scale modern packaging approaches have not yet been incorporated by the Indian feed industry sector. It is well known that attractive and convenient packaging is the important marketing strategies for any commodity which influences the buying behaviour of the customers. Thus, the adoption of modernized convenient packaging for cattle feed will not only promote its marketability; rather has capacity to infiltrate the balanced compounded cattle feed even to the poorest of the marginal and small livestock farmers of our country. A one kg branded compounded cattle feed pack present on the shelf of the grocery shop will certainly make its way to the house of livestock farmers even with small earnings who never afford a half quintal feed pack for his cattle.

Therefore, based on a case study conducted in Varanasi District of Eastern Uttar Pradesh this article presents an understanding of change in consumption pattern of branded and non-branded compounded cattle feed, change in the demand for packaged cattle feed and attitudes of the dairy farmers towards incorporation of modernized quality in packaging of compounded cattle feed.

\section{Materials and Methods}

The study was conducted by collecting data from five blocks namely Sewapuri (A), Kashi Vidyapith (B), Arajiline (C) Rohaniya (D), and Chirai Gaon (E) from each direction of the Varanasi city. 
Further, from each block, five villages were selected on random basis distributed evenly in the block. From each selected village, 10 representative dairy farmers having dairying as their primary occupation (with at least 50\% income from dairying) were selected randomly for survey. While selecting respondents, due care was taken to ensure that they were evenly distributed in the village and truly represented animal management practices prevailing in the area. The demography of the respondents including their land holding, occupational diversification, income from dairy sector and size and pattern of dairy animal holding is presented in Table 1. Primary data were collected using personal interview method and pre-tested questionnaire by on the spot observations by visiting each of the farmers. The family heads or some responsible members of the family were contacted and were explained the purpose of the visit and requested to give the answers of various questions set in the proforma. For the purpose of accuracy, data based on observations were collected by visiting the same farm at least twice. Altogether 250 dairy farmers were selected using random sampling technique. The farmers were asked questions related to use of Compounded Cattle Feed, their brand preference and questions related to packaging preferences and packaging quality which were included in the proforma. The methodology adopted for the study makes it both analytical and exploratory which analyses the current trend and future prospects of cattle feed industry in India. Further, the study explores the importance of modern packaging strategies and technologies for marketing of cattle feed products, based on the feedback from the field-based study.

Table 1: Land holding, occupational diversification, income from dairy sector and size and pattern of dairy animal holding by the respondent dairy farmers.

\begin{tabular}{|c|c|c|}
\hline \multirow{2}{*}{ Attributes } & \multicolumn{2}{|c|}{ Distribution of Respondents } \\
\cline { 2 - 3 } & $\begin{array}{c}\text { Frequency } \\
(\mathbf{n = 2 5 0})\end{array}$ & Percentage \\
\hline Land holding (ha) & & \\
\hline Landless $(<0.2)$ & 21 & 8.4 \\
\hline Marginal $(0.5 \leq 0.2)$ & 94 & 37.6 \\
\hline Small $(2.0 \leq 0.5)$ & 70 & 28 \\
\hline Medium $(5.0 \leq 2.0)$ & 45 & 18 \\
\hline Large $(\geq 5.0)$ & 20 & 8 \\
\hline
\end{tabular}

\begin{tabular}{|c|c|c|}
\hline \multicolumn{3}{|c|}{ Occuptional Diversifition } \\
\hline Dairy & 30 & 12 \\
\hline Dairy+Agriculture & 111 & 44.4 \\
\hline Dairy+Agriculture+Service & 59 & 23.6 \\
\hline Dairy+Service & 14 & 5.6 \\
\hline Dairy+Laboures & 27 & 10.8 \\
\hline Dairy+Business & 9 & 3.6 \\
\hline \multicolumn{3}{|l|}{ Total income from $\mathrm{AH}$ sector } \\
\hline$<1$ Lakh & 44 & 17.6 \\
\hline 1 to $<2.5$ lakh & 108 & 43.2 \\
\hline 2.5 to 4.0 lakh & 56 & 22.4 \\
\hline$>4.0$ lakh & 42 & 16.8 \\
\hline \multicolumn{3}{|c|}{ Size of Dairy Animal Holding } \\
\hline 1 to 2 (Marginal Dairy Farmers) & 23 & \\
\hline 3 to 7 (Small Dairy Farmers) & 127 & \\
\hline $\begin{array}{c}8 \text { to } 20 \text { (Medium Dairy } \\
\text { Farmers) }\end{array}$ & 76 & \\
\hline >20 (Large Dairy Farmers) & 24 & \\
\hline \multicolumn{3}{|l|}{ Dairy animal holding pattern } \\
\hline Indigenous cows & 15 & 6 \\
\hline Crossbred cows & 115 & 46 \\
\hline Buffalo & 35 & 14 \\
\hline Indigenous cow+Crossbred cow & 30 & 12 \\
\hline Indigenous cow+Buffalo & 21 & 8.4 \\
\hline Crossbred cow+Buffalo & 23 & 9.2 \\
\hline $\begin{array}{c}\text { Indigenous cow+Crossbred } \\
\text { cow+Buffalo }\end{array}$ & 11 & 4.4 \\
\hline
\end{tabular}

\section{Duration of study}

Visits to dairy farmers for observations and interviews and collection of data continued for three months (April-June) during the summer period of 2015.

Tabulation and analysis of data: The raw primary data obtained from respondents were tabulated and analyzed using descriptive statistics and frequency analysis using SPSS 16 software to obtain frequency and percentage of each type of information.

Results and Observations

Table 2: Preference of branding and packaging parameters in compounded cattle feed purchase by the respondent dairy farmers.

\begin{tabular}{|c|c|c|c|c|c|}
\hline Attributes & \multicolumn{5}{|c|}{ Dairy Farmers } \\
\hline & $\begin{array}{c}\text { Marginal } \\
(\mathbf{n = 2 3 )}\end{array}$ & $\begin{array}{c}\text { Small } \\
(\mathbf{n = 1 2 7})\end{array}$ & $\begin{array}{c}\text { Medium } \\
(\mathbf{n = 7 6})\end{array}$ & $\begin{array}{c}\text { Large } \\
(\mathbf{n = 2 4})\end{array}$ & $\begin{array}{c}\text { Total } \\
(\mathbf{n}=\mathbf{2 5 0})\end{array}$ \\
\hline Feed Consumption Pattern & & & & & \\
\hline Only homemade concentrate feed & 15 & 21 & 8 & 0 & 44 \\
\cline { 2 - 7 } & -65 & -17 & -11 & 0 & -18 \\
\hline Only purchased compounded cattle feed & 0 & 26 & 29 & 21 & 76 \\
\cline { 2 - 7 } & 0 & -20 & -38 & -88 & -30 \\
\hline
\end{tabular}




\section{Journal of Dairy and Veterinary Sciences}

\begin{tabular}{|c|c|c|c|c|c|}
\hline \multirow{2}{*}{ Both homemade concentrate and compounded cattle feed } & 8 & 8 & 9 & 3 & 130 \\
\hline & -35 & -63 & -51 & -12 & -52 \\
\hline \multicolumn{6}{|l|}{ Preference Of Branded Versus Non-Branded Cattle Feed } \\
\hline \multirow{2}{*}{ Non branded cattle feed } & 8 & 12 & 2 & 0 & 22 \\
\hline & -35 & -9 & -3 & 0 & -9 \\
\hline \multirow{2}{*}{ Branded cattle feed } & 7 & 92 & 68 & 24 & 191 \\
\hline & -30 & -72 & -89 & -100 & -76 \\
\hline \multirow{2}{*}{ Any type } & 8 & 23 & 6 & 0 & 37 \\
\hline & -35 & -18 & -8 & 0 & -15 \\
\hline \multicolumn{6}{|l|}{ Preference Of Packaged Versus Non-Packaged Cattle Feed } \\
\hline \multirow{2}{*}{ Non-packaged } & 9 & 14 & 12 & 3 & 38 \\
\hline & -39 & -11 & -16 & -13 & -15 \\
\hline \multirow{2}{*}{ Packaged } & 8 & 90 & 51 & 17 & 166 \\
\hline & -35 & -71 & -67 & -71 & -66 \\
\hline \multirow{2}{*}{ Any type } & 6 & 23 & 13 & 4 & 46 \\
\hline & -26 & -18 & -17 & -17 & -18 \\
\hline \multicolumn{6}{|l|}{ Preference Of Size Of Pack } \\
\hline \multirow{2}{*}{ Larger pack (50kg) } & 2 & 19 & 14 & 11 & 46 \\
\hline & -9 & -15 & -18 & -46 & -18 \\
\hline \multirow{2}{*}{ Medium pack (20/25kg) } & 9 & 45 & 26 & 13 & 93 \\
\hline & -39 & -35 & -34 & -54 & -37 \\
\hline \multirow{2}{*}{ Small pack $(10 \mathrm{~kg}, 5 \mathrm{~kg})$} & 12 & 63 & 36 & 0 & 111 \\
\hline & -52 & -50 & -47 & 0 & -44 \\
\hline \multicolumn{6}{|l|}{ Preference Of Packing Material } \\
\hline \multirow{2}{*}{ Gunny bag } & 4 & 18 & 11 & 4 & 37 \\
\hline & -17 & -14 & -14 & -17 & -15 \\
\hline \multirow{2}{*}{ Plastic bag } & 6 & 41 & 26 & 11 & 84 \\
\hline & -26 & -32 & -34 & -46 & -34 \\
\hline \multirow{2}{*}{ Polythene pack } & 13 & 68 & 39 & 9 & 129 \\
\hline & -57 & -54 & -51 & -38 & -52 \\
\hline \multicolumn{6}{|l|}{ Preference of Packing Design } \\
\hline \multirow{2}{*}{ Well designed pack } & 17 & 108 & 68 & 22 & 215 \\
\hline & -74 & -85 & -89 & -92 & -86 \\
\hline \multirow{2}{*}{ No concern for packing design } & 6 & 19 & 8 & 2 & 35 \\
\hline & -26 & -15 & -11 & -8 & -14 \\
\hline \multicolumn{6}{|l|}{ Preference of Color Combination of Pack } \\
\hline \multirow{2}{*}{ Prefer Attractive Color Combination } & 15 & 83 & 58 & 19 & 175 \\
\hline & -65 & -65 & -76 & -79 & -70 \\
\hline \multirow{2}{*}{ No concern } & 8 & 44 & 18 & 5 & 75 \\
\hline & -35 & -35 & -24 & -21 & -30 \\
\hline \multicolumn{6}{|l|}{ Eagerness to Pay For Convenience Packaging } \\
\hline Yes & 16 & 109 & 64 & 21 & 210 \\
\hline res & -70 & -86 & -84 & -88 & -84 \\
\hline No & 7 & 18 & 12 & 3 & 40 \\
\hline 1NO & -30 & -14 & -16 & -12 & -16 \\
\hline
\end{tabular}


Numerals in the parenthesis are percent value of responses of dairy farmers of either of the four categories viz. Marginal, small, medium and large.

Preference of the respondent dairy farmers for branding and packaging parameters desirable in compounded cattle feed is presented in Table 2. The majority of the respondents (81.2\%) participating in the study were small and medium size dairy farmers with average dairy animal holding from 3 to 7 and from 8 to 20, respectively. However, about 9.2\% marginal and $9.6 \%$ large dairy farmers were also in the study group. Feed consumption pattern in the study area revealed that the utilization of purchased compounded cattle feed was highest $(100 \%)$ in large dairy farmers followed by $89 \%$ in medium and $83 \%$ in small dairy farmers. The preference of branded cattle feed and packaged cattle feed was 30, 72, $89 \& 100 \%$ and 8, 90, 51 , \& $17 \%$ respectively, in marginal, small, medium and large dairy farmers. Given them a choice, almost $81 \%$ dairy farmers told that they will prefer medium $(20-25 \mathrm{~kg})$ to small $(5-10 \mathrm{~kg})$ pack size compound cattle feed instead of the big ( $\geq 50 \mathrm{~kg}$ ) pack. It was observed that, majority (52\%) of farmers will like to have polythene as their desirable packaging material followed by plastic bag (32\%) and only a few (15\%) preferred traditional gunny bags as packaging material. Majority of the dairy farmers (74-92\%) of all the groups preferred well designed pack with attractive colour combination and pictures $(65-79 \%)$ if choices will be given to them. It was further observed that the majority of the farmers in all the groups were ready to pay more prices for suitable, convenient and attractive packaging of feed materials.

\section{Conclusion}

Compound cattle feed- a commodity with nascent marketing in India, is gaining momentum now a day and has an excellent and promising scope for growth in the country. The compound cattle feed industry has been hitherto ignored by the packaging industry and personnel. The present study clearly reveals the preference of branded and packaged compounded cattle feed with suitable, convenient packaging material with attractive design and colour combination for which farmers are even ready to pay extra price. The results clearly indicate that the compounded cattle feed industry must adopt modern packaging technologies with latest packaging material and design in order to enhance sale and profitability.

\section{References}

1. Department of Animal Husbandry, Dairying and Fisheries (DAHDF) Ministry of Agriculture, Government of India. 19 $19^{\text {th }}$ Livestock census-2012, All India Report, India.

2. Alltech Global Feed Survey (2015) All Tech, 3031 Catnip Hill Road, Nicholasville, Kentucky 40356, USA.

3. Rabobank Industry Notes (2014) Rabobank Industry Estimates 2012 13. In: Feedingon Growth. Global Department of Food and Agribusiness Research and Advisory, Rabobank International, Netherlands.

4. Frost and Sullivan (2011) Strategic analysis of the Indian animal feed additives market. Frost and Sullivan Research Service, Frost and Sullivan, North America.

5. John MP, Manoj PK (2013) Marketing Strategies for Cattle Feed Products in Kerala: an Empirical Study. International Journal of Scientific Research 2(12): 9-12.

Your next submission with Juniper Publishers will reach you the below assets

- Quality Editorial service

- Swift Peer Review

- Reprints availability

- E-prints Service

- Manuscript Podcast for convenient understanding

- Global attainment for your research

- Manuscript accessibility in different formats

( Pdf, E-pub, Full Text, Audio)

- Unceasing customer service

Track the below URL for one-step submission https://juniperpublishers.com/online-submission.php 